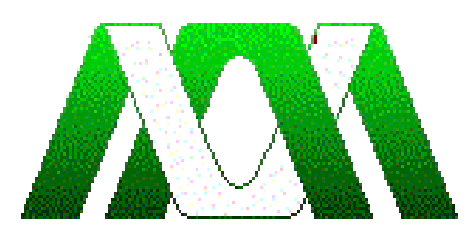

Casa abierta al tiempo

UNIVERSIDAD AUTÓNOMA METROPOLITANA

UNIDAD IZTAPALAPA

DIVISIÓN DE CIENCIAS SOCIALES Y HUMANIDADES POSGRADO EN CIENCIAS ANTROPOLÓGICAS

Fiestas patronales. La búsqueda del entendimiento de las manifestaciones y prácticas de la fe en poblaciones yucatecas.

María Beatriz Tzuc Dzib

\author{
ENSAYO \\ Para obtener el Diploma de Especialización \\ en Antropología de la Cultura \\ Director: Dr. Néstor García Canclini
}

México, D.F.

Junio de 2017 
El axioma fundamental que está en la base de lo que acaso pudiéramos llamar "la perspectiva religiosa" es en todas partes el mismo: quien quiere saber, debe primero creer.

Clifford Geertz.

\section{Fiestas patronales. La búsqueda del entendimiento de las manifestaciones y prácticas de la fe en poblaciones yucatecas.}

El tema sobre la religión, su observación, registro y análisis ha sido una línea fundamental para la antropología clásica. Es así como desde sus inicios han dado lugar a la observación de los otros a través de sus rituales y ceremonias, en donde el uso de bailes y cantos es una constante, así como los peregrinajes.

A partir de los años noventa del siglo XX el tema religioso, sus cambios, transformaciones y mezclas han tomado parte importante en los estudios antropológicos, ya que en ello se puede observar la influencia y relación entre los sistemas económicos, culturales y políticos dentro de los cuales se suscitan y desarrollan diferentes fenómenos de la sociedad en general.

En las observaciones se puede percibir la constante búsqueda de diferencias entre lo sagrado y lo profano, entre la creencia, la fe y actualmente se puede pensar en mirar la diferencia entre lo que es ser un peregrino con fe o un peregrino turista.

En este ensayo se pretende presentar un panorama de los estudios de religión que se han hecho en México, las miradas que se han desarrollado a partir de las fiestas patronales y de los peregrinajes a santuarios religiosos que se realizan en muchos de los estados de la República Mexicana. Es importante señalar que los 
trabajos a presentar son relacionados con la Iglesia católica, la religión con más tradición en el país, y que solo en apariencia es la más practicada.

Este trabajo tratará de acotar hacia ejemplos del fenómeno religioso en el Estado de Yucatán y desde los cuales se pueden realizar estudios de religión, todos ellos relacionados con ritos, actos ceremoniales e incluso los actos lúdicos dentro de las fiestas patronales.

Dichas celebraciones han sido símbolo de tradición no sólo en el estado de Yucatán sino en muchos países del mundo, cada una con sus características particulares, por lo mismo la antropología ha estado interesada en la interpretación de las prácticas, la observación de los espacios donde se llevan a cabo los rituales, los rituales mismos y demás relaciones que se dan a partir de ellas.

No se trata de un tema novedoso pero sí de un fenómeno que sigue siendo rico en información para el quehacer antropológico, sobre todo pensando en los cambios que se están produciendo en la religión y las prácticas religiosas a partir del crecimiento de las iglesias evangélicas y de la pluralidad en las creencias que se están desarrollando y mezclando.

Este ensayo plantea algunas propuestas de investigación para las fiestas religiosas, presentar antecedentes de estudios que se han realizado y hacer una reflexión sobre el carácter organizativo que se da dentro de los diferentes grupos, en las diferentes manifestaciones religiosas dentro de las fiestas patronales. Se hará un breve recuento de algunas cuestiones teóricas y metodológicas del estudio de la religión en Latinoamérica y México.

Así mismo se quiere hacer una incursión a la relación religión y turismo, teniendo en cuenta que el segundo ámbito, está en gran auge en muchos lugares del mundo, además de que en México representa una de las áreas que más alto ingreso deja al país. Su inicio con grandes centros vacacionales radicados en las playas, actualmente se puede observar la expansión del turismo tierra adentro con el turismo nombrado de diferentes maneras, como por ejemplo, turismo de arqueología, turismo de naturaleza, turismo ecológico, turismo religioso e incluso turismo académico, entre otras maneras de nombrarlo. 


\section{Tendencias en los estudios de religión en Latinoamérica.}

A partir de la segunda mitad del siglo XX los procesos de transformación en el campo religioso latinoamericano y mexicano han sido importantes y han dado lugar al desarrollo de hipótesis, opiniones y reflexiones. ${ }^{1}$ La historia de la presencia católica en Latinoamérica dejó de ser un monopolio por la relación mercantil que se desarrolló con Norteamérica y con el mercado británico, así se dio lugar a la entrada del predominio de potencias no católicas como modelo de desarrollo (Masferrer, 1991).

A partir de lo anterior la efectividad simbólica de los santos y vírgenes, patronos de las poblaciones han sido cuestionadas por el desarrollo del capitalismo que se desarrolló en el campo. Masferrer menciona que hacerles rezos y plegarias ya no era suficiente para asegurar la lluvia y las buenas cosechas. Sin embargo, a pesar de los cambios y de las apariciones de las diversas creencias religiosas diferentes a la católica, las fiestas patronales se siguen efectuando pero ahora es posible analizar otras aristas que van desde lo económico, su relación con la política actual y no solamente de tradición, fervor o cultural.

Otra de las perspectivas que se han desarrollado a partir de los cambios, ha sido el que incluye a los creyentes, la mirada como consumidores de los bienes simbólicos, los cuales abren la comprensión de la dinámica de los sistemas religiosos. La colectividad y la solidaridad que se pueden crear a partir de las organizaciones. Desde este matiz se pueden hacer cuestionamientos incumbidos con las relaciones entre los practicantes religiosos, los intereses que tiene para querer continuar dentro de la organización y práctica religiosa, entre los que se pueden distinguir los favores recibidos por intersección de los santos y vírgenes con la divinidad suprema a través.

Así mismo otro de los grandes temas de los estudios de religión, son los que relacionan a la Iglesia y el Estado, como creadora de identidad nacional. Garma (1991) realiza una reflexión sobre el abordaje que se le ha dado a través de la

\footnotetext{
${ }^{1}$ Elio Masferrer Kan. Religiones: cuestiones teórico-religiosas. Religiones
} Latinoamericanas 1. 1991. 
apropiación de símbolos religiosos, como por ejemplo en México con la Virgen de Guadalupe o la visita papal que aconteció en la década de las 90 en el siglo pasado.

Garma (1991) apunta que la secularización es un concepto polémico en el estudio de las religiones y que se deriva del desencantamiento del mundo, lo cual se refiere a la pérdida de las creencias en las esferas de lo sobrenatural, lo milagroso y los seres extraordinarios y trascendentes, todo a costa de una mayor racionalización del hombre (Weber, 1984). Se manifiesta con pérdida de la influencia de la religión en las diversas instituciones u organizaciones. Un ejemplo sería el caso de las fiestas patronales de Tizimín, en honor a los Reyes Magos, lo observado ha sido que la Iglesia no tiene influencia directa en la organización de los gremios, se podría decir que se tienen un tipo de independencia ya que se rigen por la tradición, más que por reglamentos religiosos. ${ }^{2}$

Es importante de mencionar que los estudios religiosos para el caso mexicano, y tal como apunta De La Torre $(2014,2)$ :

"se tienen que circunscribir ubicando inicialmente al catolicismo en un lugar privilegiado como religión mayoritaria (hasta hace poco monopólica), ya que mantiene una hegemonía ideológica-cultural sobre los sistemas de representaciones de los mexicanos: sus formas y contenidos de creer, valorar y celebrar los momentos que suelen ser importantes en la vida de los creyentes mexicanos."

Por otra parte John Corrigan ${ }^{3}$ (2004) apuntala otra manera de analizar los acontecimientos religiosos relacionando la emoción con religión para así poder entender cómo se construyen estructuras de orden y significado, tomando también en cuenta el idioma. Nos dice que es un enfoque poco estudiado pero de importancia y de gran complejidad, ya que se dice que las emociones son hasta cierto punto regidas por la cultura, por lo que hay que tomar en cuenta la necesidad de hacer distinciones entre lo que es la vida emocional como lo ordena la cultura y

\footnotetext{
${ }^{2}$ Hace falta indagar más profundo en ello para afirmarlo, sin embargo en la aproximación que se ha realizado es una de las cosas que se observan.

${ }^{3}$ En García, Chang (2013), p. 257. Peregrinación y Procesión. Itinerarios Religiosos Diferenciados en su Espacialización y Corporeización.
} 
la rebelión por parte de quienes la autoridad religiosa ya no significa ni les proporciona orden y ni sentido (García Chang Armando, 2013).

Estas breves notas sobres los estudios religiosos pueden ser tomadas para diseñar investigaciones para las diferentes manifestaciones religiosas que se realizan en localidades yucatecas, tanto en las organizaciones gremiales actuales, fiestas patronales, como en las peregrinaciones y precesiones; poder analizar las estrategias a las que tanto de la Iglesia católica como los gremios, han recurrido para continuar vigentes.

En México la religiosidad católica, al ser mayoritaria, y constituirse como patrimonio cultural de México, es el escenario de un sinfín de fiestas rituales, en las cuales se celebra a los santos patrones y a las vírgenes protectoras. (De La Torre 2014). Son celebraciones populares que se dan lugar a lo largo de todo el territorio mexicano, desde la frontera norte hasta la frontera sur.

Siguiendo a De la Torre (2014) fue recién en los años noventa cuando se dio lugar al crecimiento por el interés a la comprensión de la cultura de la vida cotidiana manifiesta en la religiosidad popular con las peregrinaciones ${ }^{4}$ de las fiestas religiosas ${ }^{5}$ en la vida cotidiana de los barrios urbanos. ${ }^{6}$

Si se piensa desde el medio urbano y la dinámica en la que están envueltas las grandes ciudades, se puede imaginar que se da una tendencia a la fragmentación y la dispersión, sin embargo la fiesta religiosa ha permitido la continuidad con las redes de paisanaje (Portal y Sánchez, 2010) ${ }^{7}$, y además ha contribuido a una apropiación del espacio público (anónimo y caótico) que por las prácticas se reconvierte en escenario de visibilidad grupal (Portal Ariosa, 2009) ${ }^{8}$. Así mismo se ha prestado una mayor atención al estudio de las peregrinaciones en México, pues allí se movilizan año tras año millones de creyentes que se desplazan desde los lugares donde residen a los santuarios de su devoción haciendo de "México un país peregrino" (Shadow, 1994: 15). Para estos estudios antropológicos,

\footnotetext{
${ }^{4}$ Con Garma y Shadow, 1994; Giuriati y Masferrer Kahn, 1998. En De la torre (2014). El estudio de la religión en México enmarcado en el campo intelectual y el campo del poder.

${ }^{5}$ Con Shadow, R. y Rodríguez Shadow y Valenzuela, 1999.Ibidem.

${ }^{6}$ De la Peña y De la Torre, 1990. Ibidem

7 Idem.

8 Idem.
} 
los conceptos y la metodología de los Turner $(1968,1978)$, sobre la communitas y la estructura, continúan vigentes (De La Torre 2014). ${ }^{9}$

También se han puesto atención en los cambios profundos que las prácticas religiosas populares están experimentando en la sobremodernidad, ${ }^{10}$ así como la creación o invención de renovados cultos populares, que han sido implementados como protectores de las masas para enfrentar los problemas que no encuentran respuesta en las instituciones modernas. ${ }^{11}$ A la par están surgiendo estudios e interpretaciones sobre el papel que juega la devoción popular para enfrentar los riesgos propios de una sociedad posmoderna (Gaytán en De la Torre 2014).

En la búsqueda de los estudios que anteceden a los que se proponen en este trabajo, se encuentran varios artículos sobre el estudio de la religión en México, y donde Renée de la Torre (2014) menciona que los mexicanos son definidos como ritualistas y festivos, descripción que lo relaciona con las festividades a los santos patrones y a las vírgenes protectoras de la comunidad.

El acercamiento al tema en Yucatán lo han abordado Fernández y Negroe (1997), quienes realizaron un trabajo en la población de Tetiz, población localizada al poniente del estado, y donde la Virgen es llevada a Hunucmá, sitio al que llega para ser quien encabece las fiestas patronales; su aporte es hacer visible que el santuario, en cuestión de espacios, puede tener el localizado y el ampliado, debido a la movilidad que realizan.

Otros de los trabajos que se han realizado en Yucatán es el que se refiere a la Virgen de la Inmaculada Concepción, que visita cada año el sitio arqueológico de Xcambó, localizado en el noroeste de Mérida, cada año los peregrinos asisten para venerar a la "verdadera dueña" del sitio. Se le considera así por los feligreses porque hizo aparición y las sigue haciendo para los que realmente tienen fe. De alguna manera este acontecimiento tiene un toque muy particular porque el lugar

\footnotetext{
${ }^{9}$ Como se ejemplificará más adelante.

${ }^{10}$ Con (González Torres, 2000 y 2006; De la Peña, 2002 y De la Torre, 2008 y 2008); en . En De la torre (2014). El estudio de la religión en México enmarcado en el campo intelectual y el campo del poder.

11 Tales como el culto a la Santa Muerte o la creación de sectas que tienen devoción por figuras y personajes como el Niño Fidencio (llamados fidencistas), el cual tiene lugar al norte del país y que tienen gran demanda por parte de un gran número de creyentes.
} 
permanece como sitio arqueológico. En esa celebración se dan cita tanto jmen o sacerdote maya, con el sacerdote católico, con lo que se hace muestra de que el tiempo y el lugar al peregrinar son momentos para la creación cultural (Quintal, 2000). ${ }^{12}$

Efraín Medina (2007) en su indagación en la religiosidad popular, escribe sobre el culto a la Virgen de la Candelaria de Valladolid, Yucatán, una de las fiestas que tiene gran relevancia en el estado y que ha tenido transformaciones, igual que la de Los Reyes en Tizimín, pues las actividades de ocio y entretenimiento han pasado a realizarse en espacios lejanos a los santuarios. En este artículo presenta fragmentos de relatos acerca de la Virgen, sobre el milagro que originó la celebración religiosa, sus apariciones y concesiones de milagros entre otros temas.

El santo patrón y el ts'uulli k'áak: etnografía de dos entidades sagradas en una comunidad maya de Campeche, es una investigación de David de Ángel García (2013), en donde desarrolla, como el mismo dice, una etnografía sobre el complejo mítico y ritual en la comunidad de Nunkiní, ubicada en el estado de Campeche, y el cual se le dedica a dos entidades sagradas, las cuales ocupan un lugar preeminente en el panteón local.

Ella Quintal (1993) hizo un recuento de las festividades patronales que se realizan al oriente del Estado de Yucatán, presenta una amplia descripción de lo acontecido en ellas, poniendo de manifiesto las vaquerías, las corridas de toros y también la organización gremial. Tema que le generó interés, no sólo porque son parte de la cultura de muchos yucatecos sino porque a través de ellas se puede vislumbrar el tipo de sociedades y de comunidades que las generan, recrean y transforman.

El acercamiento a los trabajos de religiosidad popular en la península, han sido de manera general y en el caso del análisis de las organizaciones gremiales, se ha tenido menor aproximación por lo que resulta ser una nueva arista que indagar a lo relacionado con la fiesta religiosas en la Yucatán. Así mismo, el estudiar los rituales a través del perfomance o las peregrinaciones con el modelo que Turner

\footnotetext{
${ }^{12}$ En Medina, Martha, y Quiñones, Teresa. Peregrinando por los Santuarios de la Península de Yucatán, P. 171.
} 
sobre communitas, estructura y antiestructura. Lo mismo que la relación entre turismo y religión, consumo de lo religioso y percepciones de los mismos peregrinos como tales y como turistas, son líneas que se pueden ir formando como áreas a investiga en Yucatán y sus fiestas.

\section{Religión.}

Una de las definiciones clásicas que se le otorgan a la religión y por medio de la cuales se pueden entender las manifestaciones religiosas que efectúan los creyentes es la que nos presenta Geertz. Como se puede ver no solo hacen referencia a las cuestiones de la religión que comúnmente se conocen, como la Iglesia católica, protestante o evangélica pues la religión es un concepto que abarca más allá de las prácticas, ya que hacen muestra de relaciones, de sistema de símbolos, de maneras de explicar la vida, las emociones, las esperanzas y de darle explicación a lo aparentemente no explicable, lo que no cabe dentro de la razón y clasificación y de un orden que el ser humano hace de lo que le rodea.

En primer lugar está la descripción que Clifford Geertz (1987) hace de este concepto:

"El hombre depende de símbolos y de sistemas de símbolos, y esa dependencia es tan grande que resulta decisiva para que el hombre sea una criatura viable, de manera que la más remota indicación de que no puede habérselas con uno u otro aspecto de la experiencia le causa la más viva ansiedad. C. Geertz.

A partir de ellos podemos hacer reflexión sobre lo que resulta inexplicable, la búsqueda de la representación de la realidad, por parte del hombre para poder vivir. Ayudan a poder elucidar el por qué el hombre se encuentra en la tierra, para qué y que lo motiva a estar. A través de los símbolos se crean modelos de la realidad con los que se dicen qué es lo bueno y qué es lo malo, qué se hace y qué no se hace, las cuales son concepciones de la realidad que se transmiten para el manejo de la vida, para el actuar. Dentro de la vida religiosa, este pensamiento es fundamental, ya que a partir de ello se dice qué es pecar o servir, es una fuente de manipulación 
para el actuar humano por parte de una autoridad no existente en la realidad, pero que se manifiesta por medio de los sacerdotes, los pastores, obispos, yo toda una estructura representada por los hombres mismos.

Tomando en cuenta esta concepción es posible manejarla para el análisis de las prácticas religiosas, ya que en ella se encuentra un sistema de reglas que los creyentes deberían seguir para poder obtener los favores positivos del Ser supremo, que en muchos casos es llamado Dios, Jehová o Yahveh. En el caso de las fiesta patronales puede decirse que los rituales llevados a cabo, como los rezos, las procesiones, los regalos que se llevan al templo, son una forma de materializar estos simbolismos de estar actuando bien, para poder ser beneficiados con la ayuda divina.

Así mismo Geertz (1987) va complementando su definición de religión diciendo:

[...] Para quienes son capaces de abrazar símbolos religiosos y mientras se atengan a ellos, dichos símbolos suministran una garantía cósmica no solo de su capacidad de comprender el mundo, sino también al comprenderlo, de dar precisión a los sentimientos que experimenta, de dar una definición a las emociones, definición que les permite experimentarlas con tristeza o alegría, hosca o altivamente. C. Geertz.

Esta parte de la definición, está claramente relacionado con el actuar bien o mal, y de ahí se desprenden sentimientos de motivaciones que va introduciendo como veremos a continuación; y que se van relacionados con la manera de concebir al mundo, de clasificarlo y de ir estableciendo un orden existencial que vaya más allá. Habla de una trascendencia del actuar más allá del actuar mismo, con una significación consistente en un marco cósmico, que va más allá del individuo.

[...] sistema de símbolos que obra para establecer vigorosos, penetrantes y duraderos estados anímicos y motivaciones en los hombres formulando concepciones de un orden general de existencia y revistiendo 
esas concepciones con una aureola de efectividad tal que los estados anímicos y motivaciones parezcan de un realismo único. C. Geertz.

Geertz apunta a que la religión tiene que afirmar algo que se relaciona con el orden y la verdad que es trascendente, y que ayuda al hombre a hacer frente al caos. Si el hombre no puede enfrentar el caos, entonces se enfrenta a una crisis que da lugar a la capacidad analítica de ver el mundo y la vida, se abre una fuerza de resistencia (que lo hace pensar en cómo se enfrenta el dolor) y a cuestionar la visión moral que se relaciona con las prácticas religiosas y las guías normativas. Es precisamente esta concepción la que es fundamental en el pensamiento de Geertz sobre la religión, es una fuerza ejercida sobre toda la realidad que más bien brinda maneras de cómo enfrentar el dolor pero no lo explica. Y se puede decir que es visible en la religión católica. Y en las fiestas patronales funciona como parte de las promesas que se le hacen a los santos y vírgenes para seguir recibiendo los beneficios espirituales y materiales de bienestar.

Para las propuestas a estudiar dentro de las las fiestas patronales, habría que analizar si lo que Geertz nos dice sobre la religión se ve reflejado y de qué manera se manifiesta y en qué rituales, peregrinaciones, o prácticas se encuentran. Es parte de las indagaciones, cuestionamientos y reflexiones que se quisieran realizar en los futuros acercamientos a los estudios religiosos en Yucatán dentro de las festividades patronales.

\section{Peregrinaciones desde el performance}

Los gremios ${ }^{13}$, procesiones y peregrinaciones en Yucatán están llenos de simbolismos, de tradición, son un patrimonio de las poblaciones y se han transmitido

\footnotetext{
${ }^{13}$ También existen los novenarios, las misas y las procesiones realizadas dentro de una misma población; estos últimos organizados por grupos que en muchas ocasiones son llamados "gremios", es posible que al leer esta palabra se piense en grupos de personas que comparten una profesión, como lo dice en su definición la Real Academia de la Lengua, pero en Yucatán ese vocablo se escucha comúnmente para referirse a una tradición realizada durante las fiestas tradicionales en los pueblos, en honor al santo patrono del
} 
por generaciones; sin embargo se han notado cambios en ellos, adaptaciones y agregaciones que forman parte de las estrategias que han utilizado para permanecer y hacerse más sólidos, o simplemente perdurar. Hacer reflexión sobre los cambios y transformaciones que se están suscitando dentro de las creencias católicas resulta relevante para el qué hacer antropológico relacionado con las religiones. Es por eso que a continuación se presentan algunas reflexiones y aproximaciones a estas nuevas miradas que se podrían desarrollar con ejemplos específicos observados de manera general en algunas poblaciones de Yucatán.

Víctor Turner entendió los motivos del declive del sistema de peregrinaje porque "ya no representaba a las comunidades si no a la antiestructura social"; se había ido impregnando de costumbres que vulneraban su espíritu inicial. ${ }^{14}$ Estas palabras de Turner están relacionadas con la concepción del peregrinaje que se tenía en un principio, el cual era hacer un viaje para visitar las reliquias de los mártires (santos), a los que se les otorgaba un poder más allá de las que tenían las plegarias.

En la actualidad se pueden observar actividades religiosas dentro de la Iglesia católica, que se manifiestan a través de peregrinaciones ${ }^{15}$ para visitar a los santos patronos de las diferentes poblaciones; así mismo estos viajes están acompañados de rituales, plegarias y cantos.

La observación, análisis e interpretación de las relaciones que se dan dentro de los rituales, de los performances que se realizan en las fiestas patronales son de interés para el trabajo antropológico, ya que representan la manera en que los creyentes conciben el mundo que los rodea y con lo que le dan significado a lo que no puede ser explicado racionalmente, otorgando de significados a símbolos materiales y no materiales para la comprensión del mundo. Los símbolos religiosos simbolizan a la propia sociedad y es un escenario al que se debería poner atención,

mismo, y que ocupan de realizar ciertas ceremonias y rituales en sus fiestas patronales, y que sí, los grupos que participan, caen en la característica de tener nombres con oficios, como chicleros, taxistas o agricultores; aunque también hay los llamados de señoras, señoritas y jóvenes

${ }^{14}$ Goody, Jack. Representaciones y contradicciones. La ambivalencia hacia las imágenes, el teatro, la ficción, las reliquias y la sexualidad. Paidós, 1999, p. 94.

${ }^{15} \mathrm{~A}$ eso se refiere el peregrinaje, ir de una población a otra. 
en lo que estos realmente hacen, influyen o repercuten e incitan a que la sociedad se reinterprete.

Fiesta patronal a los Reyes Magos en Tizimín, Yucatán.

En breve contexto Tizimín es una población que se encuentra al oriente del estado de Yucatán, a 160 kilómetros de Mérida, la capital yucateca. Cuenta con una gran extensión territorial, su base económica en gran medida depende de la ganadería y también de la agricultura. Pero su cercanía con el gran centro turístico de Cancún y la Riviera Maya en Quintana Roo, le otorga grandes ingresos a los pobladores que se trasladan a laborar a dicho lugares.

Las fiestas son fenómenos a las que se les atribuye grados de complejidad por los elementos que lo conforman, (Sarricolea y Ortega 2009), es importante hacer referencia a esto para tener un panorama sobre las prácticas en las fiestas patronales que se suscitan en las comunidades de Yucatán. Entre las aproximaciones al tema están las relacionadas con el prestigio, el reconocimiento, el reforzamiento del orden social (en tanto que evidencian o consolidan relaciones sociales), y la transmisión de mensajes simbólicos. ${ }^{16}$

La principal fiesta patronal que se da en Tizimín es en honor a los Reyes Magos y se realiza entre los últimos días de diciembre y los primeros de enero. Dentro de la misma se suscitan diversas actividades religiosas, comerciales, recreativas y de diversión. Entre las religiosas están las misas (la que es la más esperada es la celebrada por el arzobispo de la Arquidiócesis de Yucatán), las procesiones realizadas por los gremios, las peregrinaciones por parte de los antorchistas $^{17}$, la visita obligada para tocar a los Reyes, ir a prender las velas para los Reyes, la misa en el ruedo donde se realizan las corridas de toros, así como la visita de las imágenes al recinto de la feria ganadera y artesanal que se realiza en

\footnotetext{
${ }^{16}$ Sarricolea Torres, Juan Miguel y Albertina Ortega Palma, "Una mirada antropológica al estudio de los rituales festivos. La fiesta de XV años", en Dimensión Antropológica, vol. 45, enero-abril, 2009, pp. 131-152.

${ }_{17}$ Grupos de personas casi siempre conformada por hombres que realizan un peregrinaje corriendo o en bicicleta, y que llevan consigo una antorcha encendida.
} 
un lugar lejos del centro del pueblo. ${ }^{18}$ Igualmente están la otra parte de la fiesta que es la feria comercial y ganadera (como se mencionó antes).

Al no poderse abordar todos los campos aquí expuestos, este trabajo se enfocará a presentar ejemplos de las actividades peregrinas que realizan los antorchistas. Trataré de hacer la relación con el análisis que Shadow y Rodríguez Shadow brindan con su trabajo etnográfico de peregrinaje hacia Chalma. Y donde retoman el modelo de peregrinaje de Turner.

“EL PERFORMANCE, PUES, ES UNA PRÁCTICA Y UNA ESPISTEMOLOGÍA, UNA FORMA DE COMPRENDER EL MUNDO Y UN LENTE METODOLÓGICO (TYLOR, 2012)."

Lo importante del peregrinar y de las procesiones es la manera en la que se llevan a cabo. Muchos grupos de fuera hacen peregrinaciones en bicicletas, los cuales generalmente están conformados por hombres (hay poca participación de mujeres en este caso). Si seguimos lo que Elin Diamond define como performance "un hacer, un hecho"19, este peregrinar pude ser visto como un performance. El Hacer es un fundamental para el ser humano, ya que va aprendiendo e imitando, a medida que repiten e internalizan actos (Tylor, 2012). Este tipo de peregrinar se vuelve cada vez más popular. ${ }^{20}$

Así mismo el performance tiene un público, un espacio y sus participantes. En el caso de los antorchistas, su público es la gente que se encuentra dentro del templo de los Reyes Magos, muchas veces se trata de gente que está en oración y visitando el recinto religioso, pero también están los familiares esperándolos para verlos llegar luego de haber realizado un sacrificio de fe y el cumplimiento de una promesa a las figuras sagradas que representan Melchor, Gaspar y Baltazar.

\footnotetext{
${ }^{18}$ Es una fiesta comercial en donde se da lugar a la parte recreativa aparte de la fiesta religiosa durante las mismas fechas.

19 Tylor, Diana. Performance. Asunto impreso, Buenos Aires, 2012. P. 16

20 se da otra manera de peregrinaje, el cual consiste en que las personas van en una camioneta o auto, y se van turnando para ir corriendo detrás del vehículo. En la mano siempre llevan una antorcha encendida.
} 
Es por esto que se puede decir que a este grupo de jóvenes se le otorga un tipo de reconocimiento por su peregrinar. Ellos pertenecen a una colectividad distintiva debido a las promesas que deben cumplir al asistir cada año por tres años consecutivos a las antorchas. El peregrinar de este modo les brinda cierto prestigio dentro de la comunidad católica.

Siguiendo a Tylor (2012), este performance les da un sentido de pertenencia que puede ser originado desde una convención o por normativa, dependiendo de la familia, ya que muchas veces la decisión se reduce a una tradición familiar y no realmente a una convención de la persona a querer realizar el peregrinaje.

Respecto a esto podemos citar a Víctor Turner (2002) y su estudio desde los dramas sociales en el que dice: "en el drama social, aunque se hace elección de medios, fines y de afiliación social, el énfasis está principalmente en la lealtad y la obligación, al igual que en el interés [...] por lo que la gente involucrada en una manifestación religiosa como la descrita, para el cumplimiento de promesas a los santos o vírgenes, muchas veces toma decisiones en contra de sus preferencias personales. La elección es rebasada por la obligación (Turner, 2002).

A propósito del cumplimiento de promesas, en un trabajo realizado por Shadow y Rodríguez Shadow, se hace uso del modelo que Turner propone para entender la peregrinación, desde sus conceptos de liminalidad y communitas o "antiestructura" y partir de ellos dice de la peregrinación lo siguiente:

Es una experiencia social liminoide, un proceso social de movimiento y de transición que enlaza distintos dominios del cosmos. Al salir del pueblo y dirigirse a los sitios sagrados, los peregrinos emprenden un viaje por una insólita y ambigua esfera cultural cargada de atributos extraordinarios (Turner y Turner, 1978:117, Shadow y Rodríguez Shadow, 1994). 


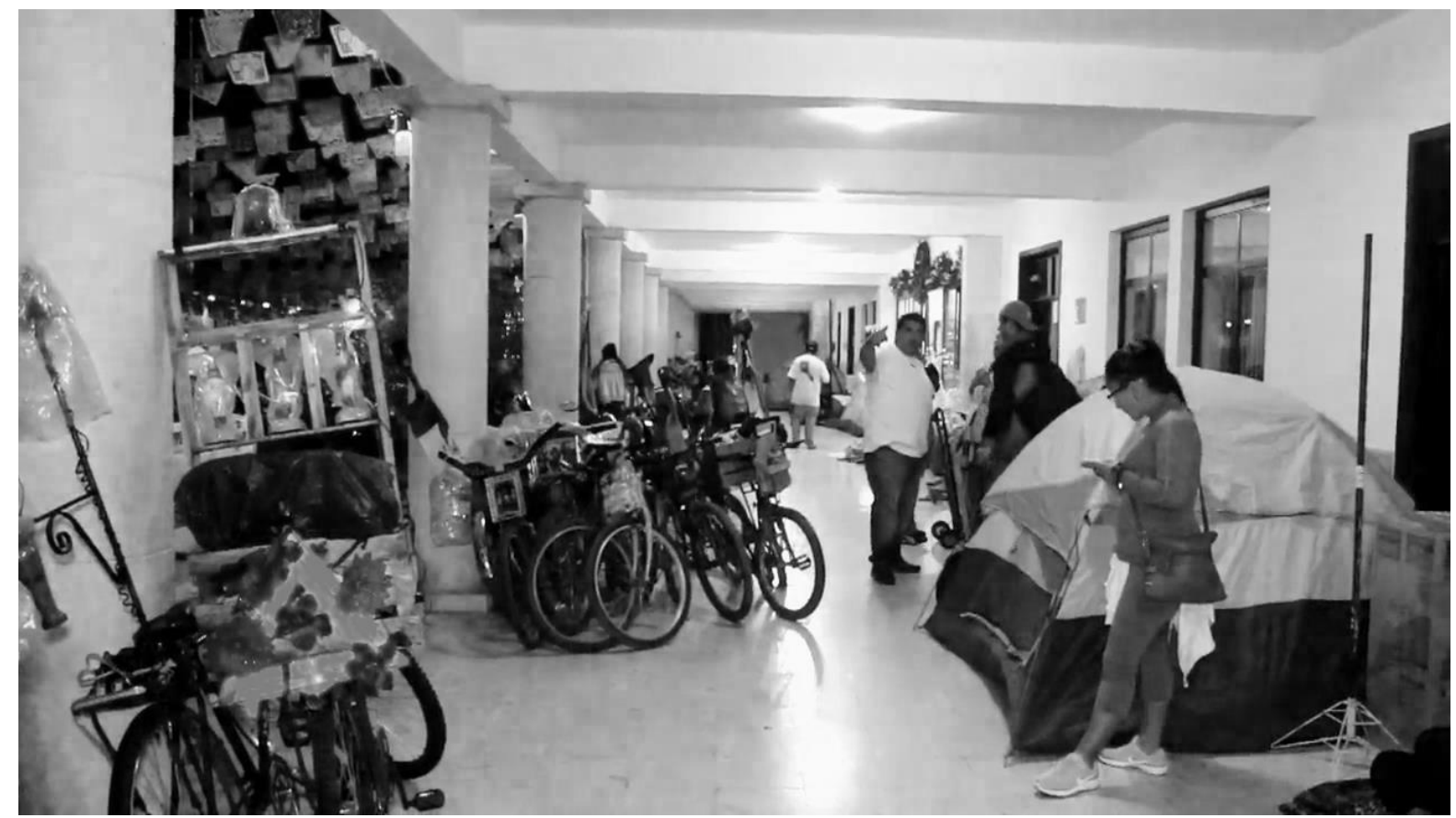

Peregrinos en los bajos del palacio municipal de Tizimín. ${ }^{21}$

Tomando en cuenta lo anterior en su análisis Shadow y Rodríguez Shadow (1994) hacen referencia a que en el peregrinaje se da lugar a una vida radicalmente distinta a la normal que surge durante el flujo de los peregrinos hacia el santuario. Que se caracteriza por el compañerismo, por la igualdad y la ausencia de jerarquía impuesta. De esto último se puede relacionar que el peregrinar que los jóvenes hacen hacia el santuario de los Reyes Magos, les brinda un espacio para estar lejos de casa y de las reglas familiares, pudiendo así vivir una aventura en carretera. Esa forma parte de una de las motivaciones por las que este grupo de personas deciden realizar este ritual peregrino. Muy distinto a lo mencionado líneas arriba, sobre la libre decisión de realizar la práctica para el cumplimiento de la promesa.

Como se mencionó más arriba el peregrinaje se realiza a base de promesas, por parte de los creyentes, para los Reyes Magos. En este caso se hace una promesa de tres años, una para cada uno y que deben ser cumplidas, si no sucediera se estaría incumpliendo y cometiendo una falta de promesas.

${ }^{21}$ Tomada de http://www.tiziminenlamira.com/?p=3818 
"GASPAR, MELCHOR Y BALTAZAR FUERON BAJADOS HOY DE SUS NICHOS PARA SER PUESTOS FRENTE AL ALTAR MAYOR DE LA IGLESIA EDIFICADA EN SU HONOR, DONDE ESPERAN LA VISITA DE MÁS DE 500 MIL PERSONAS EN LOS PRÓXIMOS 20 DÍAS."22

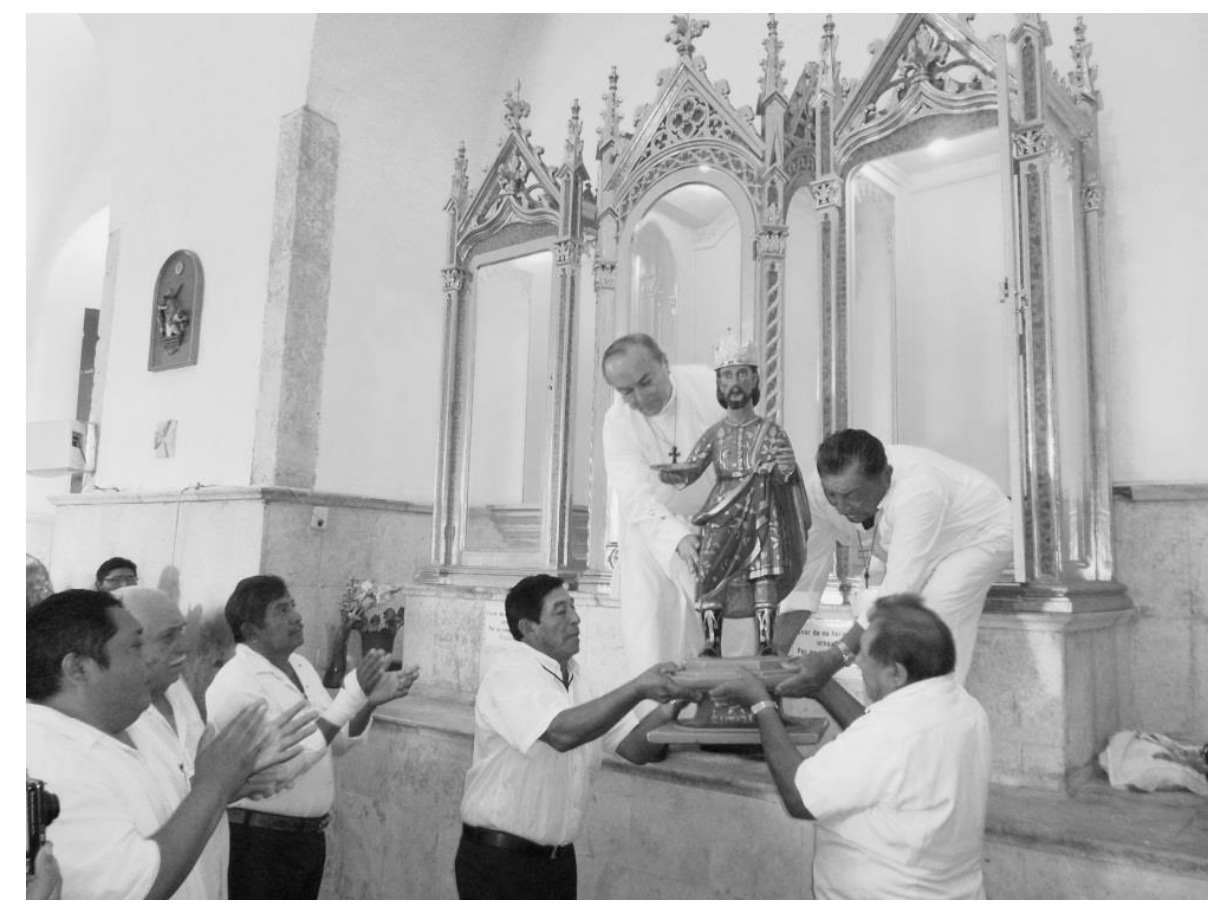

Bajada de los Reyes Magos ${ }^{23}$

Otro acto performativo que se puede observar dentro de la fiesta patronal de Tizimín es la bajada de los Reyes Magos para su celebración durante los últimos días de diciembre y primeros días de enero.

Este acto de bajar a los santos y vírgenes forma parte de los inicios de las festividades católico religiosas en las comunidades de Yucatán. Se realizan días previos a la entrada del primer gremio y ocasiones no cuenta con gran número de creyentes presentes ya que muchas veces la fecha se da en días laborales. Sin embargo es un acto importante para la comunidad. En ella participan principalmente los custodios (mayordomos), el sacerdote y creyentes. Este acto se realiza en medio

\footnotetext{
${ }^{22}$ Tomado de http://archivo.unionyucatan.mx/articulo/2015/12/29/gaspar-melchor-ybaltazar-bajan-del-altar-en-tizimin 23 lbid
} 
de una misa, con charanga, cantos. Representa el inicio de las festividades en honor a los Reyes Magos (de oriente).

Sobre esta actividad religiosa, pero en otra comunidad de Yucatán se pudo observar una manera diferente de realizar la bajada de la santa patrona, la virgen de Natividad en la comunidad de Sotuta, Yucatán. En el año 2015 fue hecho de manera diferente y con un grado de teatralidad, ya que el altar principal de la Iglesia, se encontraba rodeada de cortinas y de estructuras de luces. El nicho donde todo el resto del año está posada la virgen está a un lado. La gente esperaba que el nicho se abriera para que los custodios sacaran la imagen de Natividad hacia el altar, pero lo que sucedió fue que, mientras se escuchan cantos y plegarias, se soltó un humo alrededor del nicho mientras todos los presentes mantenían su atención en ese lado del recinto religioso, a la par las cortinas del altar principal se fueron abriendo y las luces encendiéndose. De ahí que el sacerdote con micrófono en mano pidió que se diera un aplauso a la Virgen de la Natividad que ya encontraba postrada en el altar. Sobre el acto performativo, Tylor (2012) apunta que:

" a pesar de que pareciera ser una palabra extranjera, las estrategias del perfomance están internalizadas en América Latina, donde la transmisión del conocimiento y la memoria colectiva han fungido un rol fundamental a lo largo de la historia.

A partir de esto es que el acto antes descrito sobre la virgen de la Natividad, resultó impactante para los creyentes presentes ya que lo vieron como algo que está fuera de las normas, de la estructura tradicional y de la manera en que esta práctica está arraigada en su memoria. Esto también se puede relacionar con lo propuesto por Mary Douglas ${ }^{24}$ (1980) sobre los peligros de contaminación a las creencias, normas: "nuestro comportamiento de contaminación es la relación que condena cualquier objeto o idea que tienda a confundir o contradecir nuestras clasificaciones."

${ }^{24}$ Douglas, Mary. Pureza y Peligro, un análisis de los concepto de contaminación y tabú 
Como se observó, este apartado presentó en breve la relación entre lo acontecido en las fiestas patronales y algunos conceptos desde los cuales pueden ser estudiados y analizadas algunas de las actividades religiosas en específico. Da lugar a plantear cuestionamientos para una mejor investigación del fenómeno religioso.

En concreto pienso que el perfomance, con todo el cuidado que se le debe prestar, puede ser una de los caminos a seguir para realizar un análisis de la representación simbólica que la sociedad de Tizimín le da a las actividades religiosas. Así mismo es importante mencionar lo que Turner aborda en relación a que las manifestaciones religiosas se pueden situar dentro de arenas de acción en donde los actores también se desenvuelven en varios campos. Aunque esto no se desarrolla en este trabajo, no podía quedar sin mencionar ya que es una manera de poder entender el comportamiento y desarrollo de las relaciones entre los actores miembros de las diferentes actividades religiosas realizadas dentro de las fiestas patronales.

\section{Turismo religioso}

"LO TRADICIONAL CAMBIA, LO LOCAL Y REGIONAL SE INTERNACIONALIZA, LA JERARQUÍA ECLESIÁSTICA TAMBIÉN REALIZA SUS CAMBIOS, NO SÓLO LLEGAN PEREGRINOS AL SANTUARIO, SINO QUE LA IMAGEN PEREGRINA VIAJA A LOS ESTADOS UNIDOS, SACERDOTES Y EXPOSICIONES, TAMBIÉN. LOS ARTÍ́CULOS DE VENTA EN TORNO AL CULTO LLEGAN DE ASIA, PASANDO POR EUROPA, PARA ACABAR EN HOGARES MEXICANOS O ESTADOUNIDENSES" (FERNÁNDEZ PONCELA, 2009, 91).25

Durante los siglos $\mathrm{XV}$ y XVI, los peregrinajes llegaron a ser prohibidos por la Iglesia católica alegando a que muchas veces los peregrinos perdían de vista sus objetivos. ${ }^{26}$ Esto último se relaciona con lo que se ha desarrollado actualmente en

25 En Anales de Antropología, 43, 2009, 91-116.

${ }^{26}$ Goody, Jack. Representaciones y contradicciones. La ambivalencia hacia las imágenes, el teatro, la ficción, las reliquias y la sexualidad. Paidós, 1999, p. 94. 
las poblaciones como espacios de interés turístico. Además de que se inicia a observar que muchas de las peregrinaciones daban lugar a costumbres que no cabían dentro de la estructura social y que hacían vulnerable el espíritu de los creyentes.

Como se ha mencionado anteriormente el interés de este ensayo también es presentar otras miradas para hacer el análisis de las manifestaciones religiosas como las peregrinaciones y las fiestas patronales, las cuales junto con el turismo religioso pueden inscribirse en un campo más amplio en donde se enfatice el hecho de que los rituales realizados dentro, están en constante tensión con las acciones cotidianas de los grupos sociales que producen y transmiten valores que le dan sentido a las prácticas cotidianas y a los sistemas establecidos (García Chiang, 2013, 266).

Así mismo y coincidiendo con García Chiang, Patricia Arias nos dice de las fiestas patronales:

[...] se sabe que la fiesta patronal ha sido un evento clave y persistente en la vida de las comunidades, en especial, de las comunidades rurales en América Latina; ha sido, además, un tema tradicional de los estudios antropológicos por ser un espacio privilegiado donde se intersectan lo público y lo privado, donde se expresan las relaciones y los compromisos de los grupos sociales que participan en ella, donde se afirman, pero también se recrean, las pertenencias comunitarias y la producción de orden y sentido para las sucesivas generaciones (González Montes, 2006; Lameiras, 1990; Medina, 1995).

Las fiestas patronales son sucesos que dan lugar a la presencia de multitudes conformadas por gente de la comunidad, por gente que regresa luego de mucho tiempo de no residir ahí, así como de invitados o personas que por diferentes medios van conociendo sobre la realización de las fiestas. Las personas externas a la comunidad y que llegan de visitantes generalmente se enteran de las bendiciones otorgadas a los fieles y es uno de los motivos por el que asisten; otras lo hacen por comercializar o simplemente como parte de un paseo a otra población y para asistir a las actividades lúdicas que ahí se realiza, como los bailes, las corridas de toros o las charreadas. 
Por todo este intercambio y movilización de gente, la transformación de las localidades, el incremento de infraestructura, así como la mejora en las vías de trasporte, hoy se puede decir que la religiosidad popular crece y el turismo religioso se oficializa, divulga y fomenta de forma especial por las secretarías de turismo de los gobiernos correspondientes y también por las autoridades eclesiásticas. La Identidad regional, la religiosa y la comercial tradicional convergen para dar lugar al desarrollo de un turismo religioso y cultural. Se podría pensar que ya no existen fronteras para la fe, el consumo y el turismo (Fernández Poncela, 20012, 29).

Esto último es otra de las propuestas que se tienen para analizar en las fiestas patronales de algunas de las comunidades del Estado de Yucatán, en donde se han estado dando saltos enormes para la recepción de numerosos peregrinos, turistas o visitantes Estas festividades siguen siendo materia de observación para la comprensión de las sociedades y de las nuevas relaciones entre los actores de las poblaciones y los de fuera. El turismo está influyendo en los cambios del paisaje en las comunidades así como en la dinámica económica y cultural de los pobladores, por lo que es momento de tomar estos indicadores e iniciar a indagar sobre este fenómeno. Relacionado con esto, García y Marín $(2012,11)$ nos dicen que:

"el turismo es una fuerza de gran poder de penetración y transformación económica y sociocultural, nos obliga no sólo a seguir los pasos de los grandes cambios y comprender su naturaleza desde una perspectiva estrictamente académica, sino igualmente discutir nuestro futuro a través de los mundos concretos, las aversiones y los sueños que construye nuestra propia sociedad."

Existen trabajos que abordan el traslado de los peregrinos hacia los lugares sagrados de los centros religiosos católicos, tales como la Catedral de San Pedro, en el Vaticano o la Basílica de Guadalupe en México ${ }^{27}$, los cuales desde hace años

${ }^{27}$ Por el santuario de Guadalupe se calcula que pasan de 12 a 14 millones de peregrinos o visitantes al año (4 millones cada diciembre). Martínez y Ruezga. Cuaderno 14.

En la Basílica de Guadalupe en la Ciudad de México es muy fácil ver manifestado el turismo, pues se puede observar una ruta de Turibus, que llega ahí, además de que en varios puntos se encuentra establecidos puestos de fotografía para que los peregrinos se lleven el 
han estado transformándose como sitios turísticos potenciales, visitas que no siempre están relacionadas con religiosidad o devoción.

La basílica de Guadalupe en la Ciudad de México es un punto importante de expresión religiosa que se conjuga con el turismo. Diariamente recibe miles de visitantes y la manera en la que está conformado el recinto, da lugar a que el recorrido te pueda llevar algunas horas. Cuenta con diversas capillas en las que se suscitaron diferentes acontecimientos que forman parte de la historia de la iglesia católica mexicana. Cuenta con museos y tiendas de recuerdos religiosos oficiales (los que están dentro del recinto) y los puestos y plazas que se encuentran fuera.

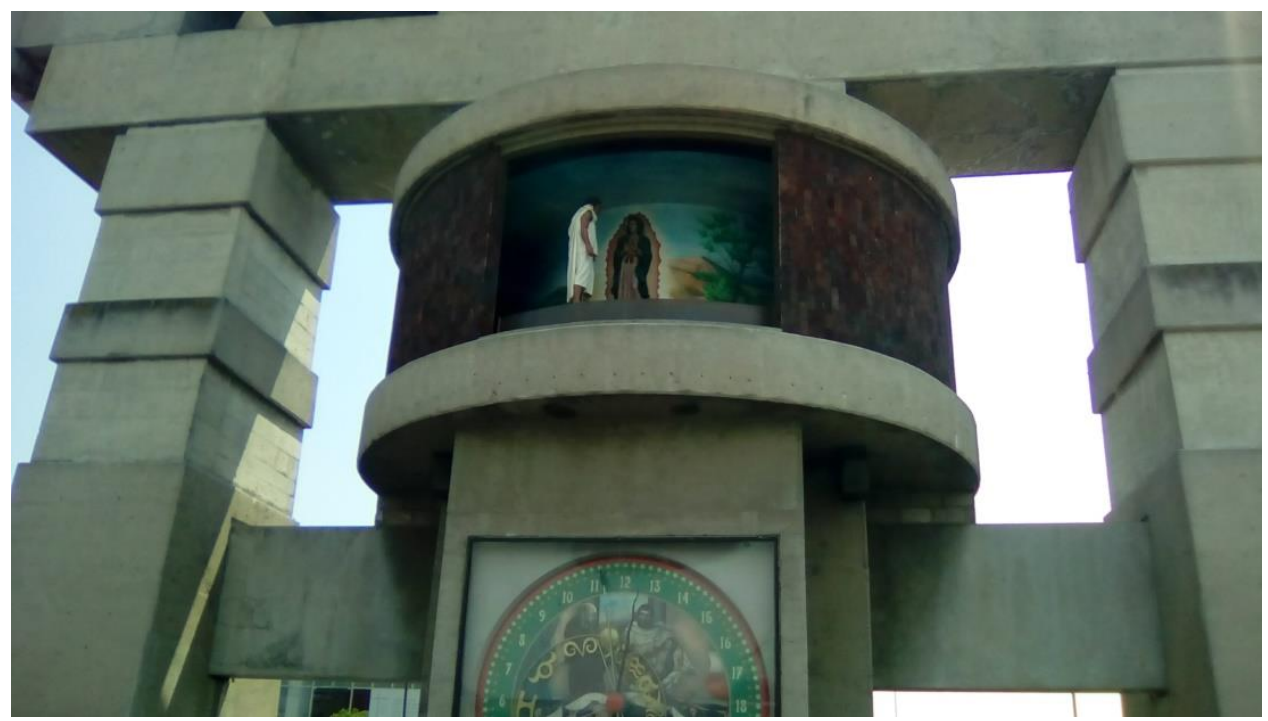

Representación de la aparición de la virgen de Guadalupe a Juan Diego ${ }^{28}$

Si apuntamos hacia una mirada micro y ponemos atención a otros centros, menos conocidos a nivel mundial, también se puede observar este tipo de manifestación. Por ejemplo en Yucatán han existido rutas turísticas que involucran templos católicos, como la ruta de los conventos.

Igualmente García Chiang (2013) hace mención de la Virgen de Montserrat en España, sitio que ha sido objeto de distintas significaciones pre-cristianas y

recuerdo de su visita. Ya sea en el cerro del Tepeyac o en los diferentes espacios donde están las imágenes que representan la manifestación de la Virgen del Tepeyac a Juan Diego. Así mismo que hay una presentación con narración que se hace a medio día sobre ese mismo episodio de aparición a San Juan Diego.

${ }^{28}$ Foto de María Tzuc. Ciudad de México. Enero de 2017. 
apropiaciones diversas, hasta su identificación patriótica, pasando por la iconografía católica, y también da muestra del paso de un lugar de culto a una visita turística transforma a los sujetos de peregrinos a consumidores turísticos.

Con respecto a lo anterior Fernández Poncela (2012) señala que actualmente hay algo más a destacar sobre la definición de religiosidad popular. Y se refiere al cómo se da lugar a la expansión de la devoción más allá de lo local o regional, más allá incluso de lo puramente religioso, como cuando las imágenes y santuarios se internacionalizan, cuando los devotos se mueven de lugares más lejanos, haciendo que las imágenes religiosas viajen a otros países a través de estampas, fotografías, llaveros, artesanías, esculturas, medallitas o cualquier otro tipo de recuerdo.

Otro tema de importancia es el que se relaciona con que las líneas comerciales también se expanden y por lo mismo, las autoridades políticas abren rutas religiosas para el turismo, lo que se ofrece como un medio de vida a la comunidad. Esta expansión puede ser vista y utilizada como una forma para potencializar la evangelización ${ }^{29}$, cuestión que también sería relevante analizar en medio de los cambios en las creencias y las diversas maneras de manifestar religiosidad, tomando en cuenta la pluralidad de religiones que están emergiendo.

La iglesia y el Estado están tomando cartas importantes en el asunto, junto con la iniciativa privada y la sociedad donde se ubica la imagen y el templo concreto. En general Iglesia, Estado y sociedad van de la mano en este esfuerzo, con un objetivo compartido y relacionándose asertivamente (Fernández Poncela, 2012, 32).

\footnotetext{
${ }^{29}$ La iglesia católica desde la década del 60 favorece la promoción del tiempo del turismo como un tiempo de salvación del individuo, haciendo del turismo religioso un medio para la catequesis. Para ello intentan tomar del turismo su característica de manifestación cultural y realizar un "re descubrimiento" y una revalorización del arte de la iglesia y del rescate de los testimonios de valores y humanidad "encarnada " en la arquitectura, en la escultura y pintura cristiana con el lema: "la vida se ha hecho visible, la comunicación de la Fe a través del arte" (Boletín informativo del Consejo Pontificio del Vaticano №31 en Puccio, 2002).
} 


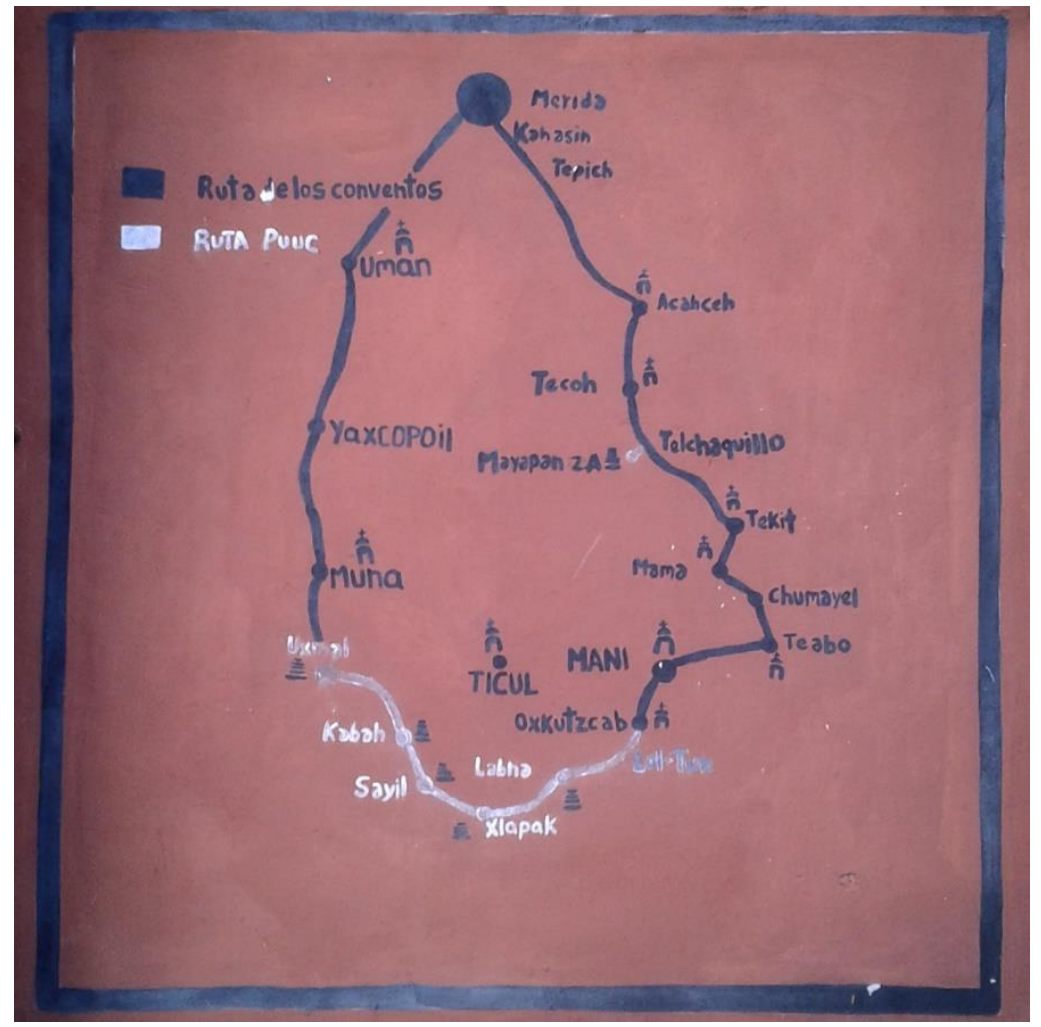

Ruta de los Conventos En el Estado de Yucatán. ${ }^{30}$

Entre las líneas a seguir para analizar religión y turismo se encontró con algo que Alicia Puccio (2002) menciona en su artículo El turismo y su relación con la religiosidad popular, y que va de la mano con lo mencionado acerca de los cambios que se suscitan en la organización de las poblaciones y que se relacionan con la economía de las mismas. En esta relación tendrían que analizarse los cambios en la organización social y económica que se dan en el espacio donde se manifiesta la fiesta patronal.

Este tipo de indagaciones han sido más trabajadas en lugares de España, como se mencionó líneas arriba en la peregrinación a la Virgen de Montserrat. Así mismo es de importancia recalcar que los estudios con enfoque antropológico son escasos y más en el estado yucateco.

Otras investigaciones relacionadas las han hecho Anna María Fernández Poncela, a quien se le ha mencionado a lo largo de este trabajo con sus artículos La religión popular en la globalización y La Virgen de Talpa. Religiosidad, Turismo y Sociedad.

${ }^{30}$ Foto de María Tzuc. Maní, Yucatán. Noviembre de 2014. 
Durante el proceso de búsqueda para este trabajo, se encontraron diversos artículos relacionados con el turismo religioso desde las disciplinas económicas, de la geografía y el turismo. Entre ellos El turismo religioso en los altos de Jalisco y Andalucía: comparación de la oferta y demanda en dos santuarios marianos. ${ }^{31} \mathrm{En}$ mencionado texto se indaga sobre el creciente flujo de migrantes turistas que se hacen presentes en el santuario de la Virgen de San Juan de los Lagos. Hace una comparación con la ruta religiosa en Andalucía, España, para analizar la experiencia sobre la creación de rutas turísticas.

Otro de las reflexiones lo hace Aulet Serrallonga y Hakobyan (2011) en donde se plantean ¿Cuáles son las razones que mueven a los turistas a visitar estos lugares? (los recintos religiosos), así como se trata de conceptualizar el término turismo religioso a partir del llamado turista, peregrino o turista cultural.

\section{Pueblo de las tres culturas.}

En Yucatán se encuentra la población de Izamal, ciudad que actualmente es uno de los pueblos mágico del estado. Se le caracteriza por su centro histórico amarillo, ya que todos los edificios que conforman las calles principales, están pintados de ese color. En 1993 su ex Convento de San Antonio de Padua fue sede de una de las visitas de S.S Juan Pablo II a México. Ahí es donde se llevó a cabo una misa que reunía a las etnias de Latinoamérica, ceremonia en donde también se llevó a cabo la simbólica coronación de la Virgen de la Inmaculada Concepción, también llamada Reina y Patrona de Yucatán.

Es un recinto religioso en el que se realiza la importante fiesta religiosa, de la ya mencionada Virgen de Concepción, durante el periodo del 29 de noviembre al 8 de diciembre es visitada y venerada en la población. Por su carácter de población mágica, de presumir tener el atrio más amplio de los recintos católicos en Latinoamérica, además de llamarse ciudad de las tres culturas, Izamal puede ser tomada como un municipio de importancia para el desarrollo de turismo religioso en Yucatán. Es unos de los destinos más publicitados en los folletos y videos, se han

${ }^{31}$ Carranza, Martínez, Millán Vázquez (2011). 
hecho diversos reportajes y cortos documentales de su historia y sobre cómo llegó la Virgen de la Inmaculada Concepción al pueblo.

En Yucatán aún no se tiene fijado la mirada para el estudio del turismo religioso, como se ha hecho en otras áreas como el turismo de playa o de arqueología. Y siguiendo los antecedentes que se tienen sobre esta línea en otros estados de México, se considera que es preciso iniciar las aproximaciones académicas a esta área de la península.

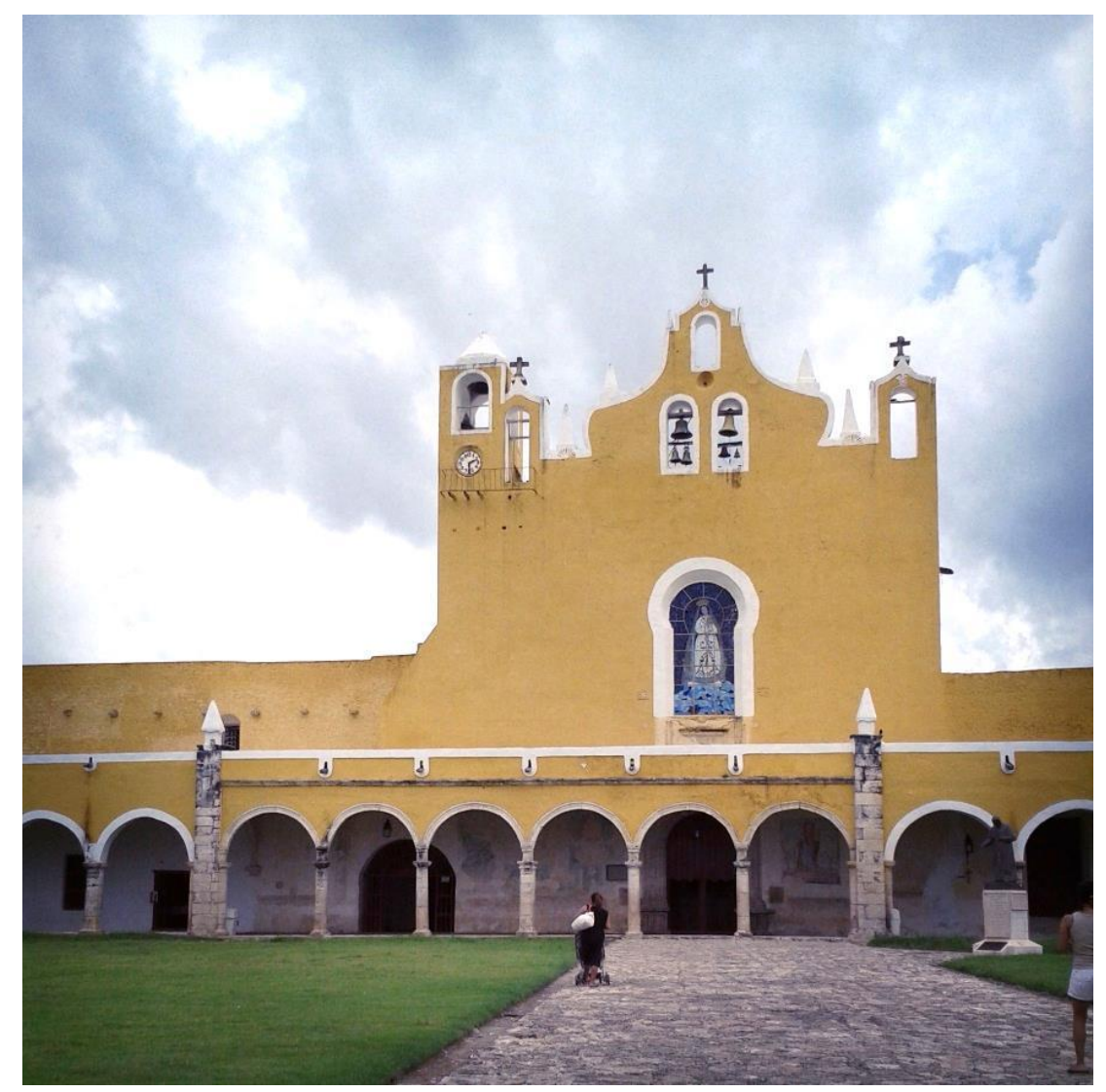

Foto Ex Convento de San Antonio de Padua en Izamal, Yucatán. ${ }^{32}$

Tomando en cuenta lo que Shadow y Rodríguez Shadow(1994,19-21) nos dicen sobre el peregrinaje:

32 Foto de María Tzuc. Julio de 2014. 
"Los centros de peregrinación pueden también ser vistos como espacios de un poder alternativo, en donde se expresan no simplemente mensajes de integración sino también deseos utópicos de bienestar que contrastan fuertemente con la realidad de la existencia cotidiana representada por la instituciones dominantes"

Este punto de reflexión podría ser motivo de análisis, sobre el por qué los creyentes o no creyentes ven en las procesiones y peregrinaciones, de los espacios religiosos, de ese camino que recorren para la muestra de su devoción.

Izamal puede ser vista como un potencial espacio de análisis en relación con turismo y religión. Contiene varias características que permitirían enriquecer la investigación de los estudios de religión para la antropología actual. Ese es el interés principal de la exploración presentada en este trabajo, poder mostrar y dar lugar a espacios de reflexión sobre este tema a un nivel más regional. Es el porqué de introducirla brevemente en este trabajo que en el futuro se pretende ser ampliado a manera de más análisis en cada una de las prácticas religiosas que se realizan en ese sitio.

A manera de conclusiones, y de modo breve, se pretendió hacer la relación del modelos que Turner propuso, al igual que hacer uso de los concepto de religión y así hacer muestra de aristas diversas desde las que se puede hacer un estudio sobre las manifestaciones religiosas que se realizan en las fiestas patronales dentro de la Iglesia católica. El espacio deja poco para indagar sobre las organizaciones gremiales o más sobre la organización de los antorchitas, pero da una idea general para la continuidad de los estudios de las fiestas patronales.

El hacer una breve aproximación del uso del performance para el análisis de los rituales, resulta ser de gran interés para esta autora. Además da lugar a reflexiones que lleven a encontrar maneras diferentes de abordarlas y compararlas con los estudios que ya están realizados por investigadores locales del Estado con respecto a las movilizaciones peregrinas de los diferentes santos y vírgenes. Los trabajos revisados desde en la literatura a partir de enfoques turísticos, económicos y sociales ayudan a plantearse cuestionamientos desde el turismo religioso con las variadas descripciones de las fiestas patronales desde su carácter religioso y comercial. Pero también cuestiones sobre el peregrino, ¿se le puede llamar turista? 
El peregrino mismo ¿se llamaría turista? ¿Reflexionará sobre su acción de peregrinaje? $Y$ muchas otras preguntas que habrá que seguir elaborando para la continuación de los estudios de religión y que pueden relacionarse con muchos otros aspectos dela vida cotidiana, como la identidad, el prestigio que te da pertenecer a algún gremio. La fe misma y las maneras en que los creyentes la manifiestan, así como el porqué de manifestarla de una u otra manera. Analizar el porqué de acudir a una fiesta patronal, colaborar u organizarla. 


\section{Bibliografía}

Alexander, Daniel, Antes Peter, et al. (1991), "Nuevos Movimientos y Tendencias Religiosas en América Latina", Masferrer, Elio. "Cultura y Procesos de Secularización“, Garma, Carlos. Religiones: Cuestiones Teóricos-Metodológicas. Religiones Latinoamericanas 1. México.

Arias, Patricia (2011). La fiesta patronal en transformación: significados y tensiones en las regiones migratorias. Migración y desarrollo, 9(16), 147-180. 2017 Consultado el 30 de marzo de 2017. Disponible en: http://www.scielo.org.mx/scielo.php?script=sci arttext\&pid=S1870$\underline{75992011000100005 \& \operatorname{lng}=e s \& \text { tlng=es. }}$.

Aulet Serrallonga Silvia y Hakobyan Karine (2011). Turismo Religioso Y Espacios Sagrados: Una Propuesta Para Los Santuarios De Catalunya. En revista Iberoamericana de Turismo - RITUR, Penedo, vol. 1, n. 1., p. 63-82, 2011. ISSN 2236-6040. Disponible en: http://www.seer.ufal.br/index.php/ritur

Carranza Roberto Carlos, Martínez Rogelio, Millán Vázquez de laTorre Ma. Genoveva (2011). El turismo religioso en los altos de Jalisco y Andalucia: comparación de la oferta y demanda en dos santuarios marianos. Recuperado el 13 de junio de 2017. Disponible en:

https://idus.us.es/xmlui/bitstream/handle/11441/53089/carranzamillan.pdf?sequence $=1$.

De Ángel García, David (2013). El santo patrón y el ts uulli k'áak: etnografía de dos entidades sagradas en una comunidad maya de Campeche. Universidad Complutense de Madrid.

De la Torre, Renee (2014). El estudio de la religión en México enmarcado en el campo intelectual y el campo del poder. Sociedad y Religion №42, Vol XXIV (2014), pp. 67-91.

Douglas, Mary (1980). Pureza y Peligro, un análisis de los concepto de contaminación y tabú. Siglo XXI, España.

Fernández Poncela, Anna María (2012). La Virgen de Talpa: religiosidad, turismo y sociedad. Política y Cultura, Sin mes, 29-48. Recuperado el 6 de junio de 2017. Disponible en: http://www.redalyc.org/pdf/267/26725009003.pdf

Fernández Poncela, Anna María (2009), 91-116. La religiosidad popular en la globalización. En Anales de Antropología, No. 43. 
Fernández Francisco Y Negroe, Genny. Caminando y paseando con la Virgen. Prácticas de la religión popular e identidades sociales en el noroeste de Yucatán, en Identidades Sociales en Yucatán, pp. 99-131. M.C. Lara (comp.). Mérida: Universidad Autónoma de Yucatán, Facultad de Ciencias Antropológicas.

Fernández Repetto, Francisco y Genny Negroe Sierra (1997) "Resistencia cultural a través de la religión popular. Los gremios y las fiestas de Yucatán", en Persistencia cultural entre los mayas frente al cambio y la modernidad, Ramón Arzápalo Marín y Ruth Gubler (compiladores). Mérida: Universidad Autónoma de Yucatán.

García Chang Armando (2013). Peregrinación y Procesión. Itinerarios Religiosos Diferenciados en su Espacialización y Corporeización. Cuerpos, Espacios y Emociones. Aproximaciones desde las Ciencias Sociales. Aguilar, Miguel Ángel y Soto Villagrán Paula Coords.

Geertz, Clifford (1987). La Interpretación de las Culturas, cap 4. "La religión como Sistema Cultural'. Gedisa, México.

Goody, Jack (1999). "Reliquias y la contradicción cognitiva de los restos mortales y de los deseos de inmortalidad" en Representaciones y contradicciones. La ambivalencia hacia las imágenes, el teatro, la ficción, las reliquias y la sexualidad. Paidós.

Marín Guardado Gustavo, García de Fuentes Ana, Daltabuít Godás Magalí Coords (2012). Turismo, Globalización y Sociedades locales en la Península de Yucatán, México.

Martínez Cárdenas Rogelio y Ruezga Gutiérrez Silvano. El turismo por motivación religiosa en México. El caso de San Juan de los Lagos. En Cuaderno 14. Planeando sobre turismo cultural. Consultado 21 de junio de 2017. Disponible en: http://www.cultura.gob.mx/turismocultural/cuadernos2.php

Medina Alcocer, Efraín (2007) Entre apariciones y milagros, el culto a la Virgen de la Candelaria en Valladolid. Temas Antropológicos. Vol. 29, núms. 1-2, págs. 141-169.

Medina, Martha y Quiñones, Teresa. Peregrinando por los Santuarios de la Península de Yucatán, en Estudios de la Cultura Maya XXVII, pp. 165-180. Instituto Nacional de Antropología e Historia, Centro Yucatán. 
Puccio, Hilda (2002) El Turismo y su relación con la religiosidad popular. Argentina. Memorias Coloquio internacional "Geografía de las Religiones". Consultado el 19 de junio de 2017. Disponible en: http://observatoriogeograficoamericalatina.org.mx/egal8/Geografiasocioeconomica/ Geografiaturistica/27.pdf

Quintal Avilés, Ella (1993). Fiestas Y Gremios En El Oriente De Yucatán. Yucatán: Identidad Y Cultura Maya. Universidad Autónoma De Yucatán. Recuperado el 18 De Enero De 2016.

Disponible en Http://Www.Mayas.Uady.Mx/Articulos/Fiestas.Html

Quintal Avilés, Ella. Vírgenes e ídolos: La religión en las manos del pueblo, publicado en Revista Mesoamérica 39 (junio de 2000), págs. 287-304. Recuperado el 19 de enero de 2016.

Disponible en: http://www.mayas.uady.mx/articulos/virgenes.html

Sarricolea Torres, Juan Miguel y Ortega Palma Albertina, (2009) "Una Mirada Antropológica al estudio de los rituales festivos. La fiesta de XV años", en Dimensión Antropológica, vol. 45, enero-abril, 131-152. Consultado el 30 de marzo de 2017. Disponible en:

http://www.dimensionantropologica.inah.gob.mx/?p=3020.

Shadow Robert, Rodríguez Shadow María (1994) "Símbolos que amarran, símbolos que dividen." Las peregrinaciones religiosas: una aproximación. Carlos Garma y Roberto shadow (coords). UAM.

Tylor, Diana (2012). Performance. Asunto impreso, Buenos Aires.

Turner, Víctor. Antropología del Ritual. INAH. México, 2002

Turner, Víctor, Geist, I. (2002). Consejo Nacional para la Cultura y las Artes (México), Instituto Nacional de Antropología e Historia (México), \& Escuela Nacional de Antropología e Historia (México). Antropología del ritual. México: CONACULTA.

Turner, Víctor (1974). Dramas, Fields and Metaphors, Cornell University Press, Ithaca London.

Peregrinos y Antorchitas llegan a Tizimín. Consultado en:

http://www.tiziminenlamira.com/?p=3818 
A9I

Casa dherta $\mathrm{x}$ sempo

UNIVERSDAD AUTONONA METROPOUTANA-VTAPALAPA

ONISOON DE CIENCUS SOCIALES Y HUMARDADES

POSGRADO EN GIENCIAS ANTROPOLOGIEAS

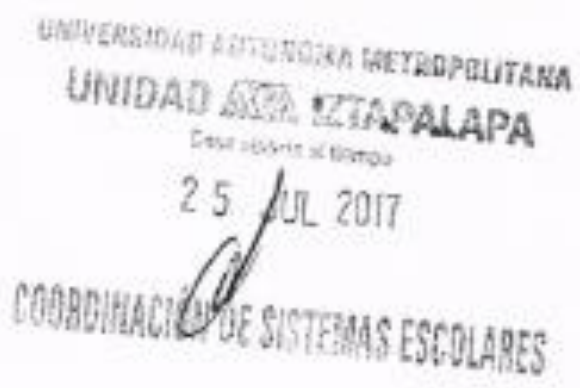

CONSTANCIA DE EVALUACIÓN DEL ENSAYO

PARA LA OBTENCIÓN DEL DIPLOMA EN LA ESPECLALIZACIÓN EN ANTROPOLOGIA DE LA CULTURA

\begin{tabular}{|l|l|l|}
\hline Nas & Mes \\
19 & 97 & 2017 \\
\hline
\end{tabular}

ALUMNA: TZUC DZIB MARIA BEATRIZ

MATRICULA: 2163301314

TEIMESTRE 17-F

LA ALUMNA PRESENTÓ EL. ENSAYO TITULADO:

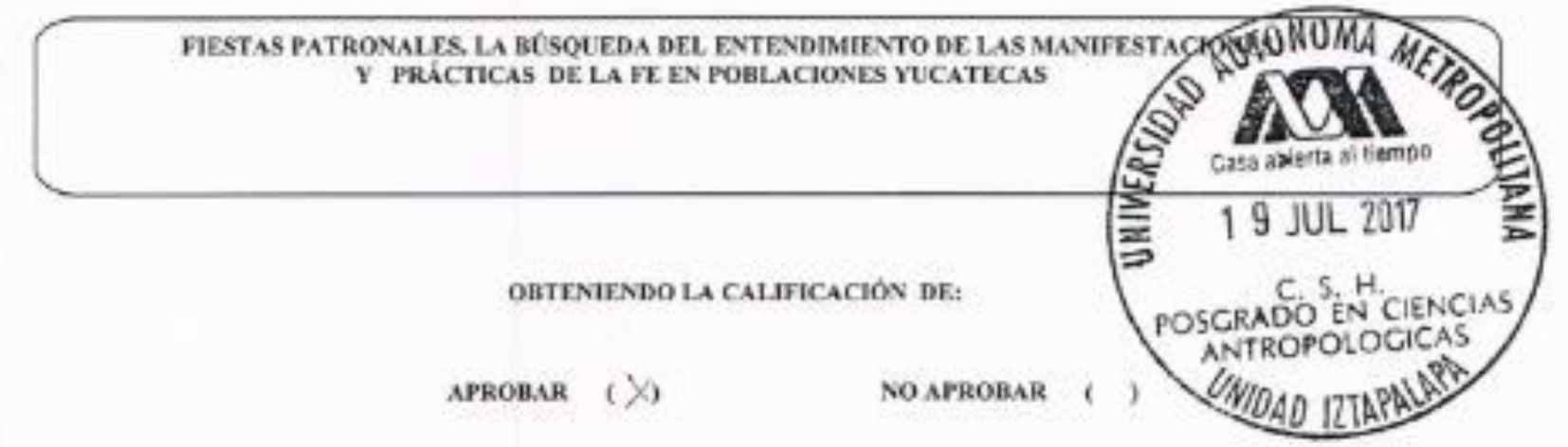

DIRECTOR DEL. ENSAYO

DR. NÉSTOR RAÓL GARCKK CANCLIVI

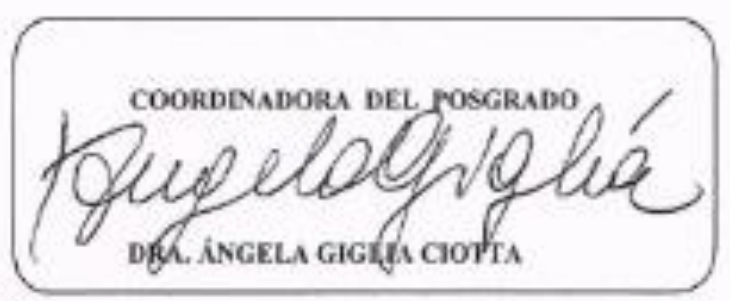

